\title{
Uji daya hambat ekstrak bunga cengkeh (Syzygium aromaticum) terhadap bakteri Porphyromonas gingivalis
}

\author{
${ }^{1}$ Agrianto Paliling \\ ${ }^{2}$ Jimmy Posangi \\ ${ }^{3}$ P. S. Anindita \\ ${ }^{1}$ Kandidat Skripsi Program Studi Pendidikan Dokter Gigi Fakultas Kedokteran \\ ${ }^{2}$ Bagian Farmakologi dan Terapi Fakultas Kedokteran \\ ${ }^{3}$ Program Studi Pendidikan Dokter Gigi Fakultas Kedokteran \\ Universitas Sam Ratulagi \\ Email: agriantopaliling@gmail.com
}

\begin{abstract}
Cloves (Syzygium aromaticum) are commonly found in tropical territory. Flower bud of cloves contains cloves essential oil with its main compound is eugenol. Porphromonas gingivalis is an anaerob Gram negative bacterium which is one of the normal floras in oral cavity. However, it has the ability to cause an infection such as periodontitis. This study was aimed to determine the inhibition effect of cloves flower bud extract on Porphyromonas gingivalis growth through the diameter magnitude of the inhibition zone. The category of inhibition zone was based on Davis and Stout. This was an experimental study using Kirby-bauer modification method. Cloves flower bud samples were obtained from Senduk Tanawangko and were extracted with maseration method using etanol $96 \%$. Porphyromonas gingivalis bacteria were obtained from pure bacteria stock in the Laboratory of Microbiology Faculty of Medicine, University of Hasanuddin Makassar. The results showed that the average diameter of inhibition zone of cloves flower bud extract against Porphyromonas gingivalis was $13.01 \mathrm{~mm}$. Conclusion: Cloves flower bud extract had a strong ability to inhibit Porphyromonas gingivalis growth.
\end{abstract}

Keywords: cloves flower bud, Porphyromonas gingivalis, inhibition zone

\begin{abstract}
Abstrak: Tanaman cengkeh (Syzygium aromaticum) merupakan tanaman yang banyak tumbuh di daerah beriklim tropis. Bunga cengkeh mengandung minyak atsiri (clove essential oil) dengan kandungan utama ialah eugenol. Porphyromonas gingivalis ialah bakteri anaerob Gram negatif yang merupakan salah satu bakteri flora normal dalam rongga mulut tetapi jika berlebihan dapat menyebabkan penyakit periodontitis. Penelitian ini bertujuan untuk mengetahui daya hambat ekstrak bunga cengkeh terhadap Porphyromonas gingivalis yang dinilai melalui besar diameter zona hambat yang terbentuk. Kategori daya hambat berdasarkan penggolongan Davis dan Stout. Jenis penelitian ialah eksperimental dengan metode modifikasi Kirby-Bauer menggunakan sumuran. Sampel bunga cengkeh diambil dari Desa Senduk Tanawangko kemudian diekstraksi dengan metode maserasi menggunakan pelarut etanol 96\%. Bakteri Porphyromonas gingivalis diambil dari stok bakteri murni yang diperoleh dari Laboratorium Mikrobiologi Fakultas Kedokteran Universitas Hasanudin. Hasil penelitian mendapatkan nilai rerata diameter zona hambat ekstrak bunga cengkeh terhadap bakteri Porphyromonas gingivalis sebesar 13,01 mm. Simpulan: Ekstrak bunga cengkeh memiliki daya hambat kuat berdasarkan kategori Davis dan Stout terhadap bakteri Porphyromonas gingivalis.
\end{abstract}

Kata kunci: bunga cengkeh, Porphyromonas gingivalis, zona hambat 
Kesehatan gigi dan mulut merupakan suatu hal yang sangat penting untuk diperhatikan karena memengaruhi kualitas hidup termasuk fungsi pengunyahan, fungsi bicara, dan percaya diri. Berdasarkan Riset Kesehatan Dasar Nasional 2013, prevalensi masalah kesehatan gigi dan mulut di Indonesia adalah 25,9\%. Hal ini disebabkan karena masih kurangnya kesadaran dan pengetahuan masyarakat mengenai pentingnya kesehatan gigi dan mulut yang jika tidak diperhatikan dapat menimbulkan penyakit di sekitar rongga mulut. Masalah kesehatan gigi yang cukup umum ditemukan dalam rongga mulut yaitu masalah karies gigi dan penyakit periodontal. $^{1}$

Penyakit periodontal merupakan masalah kesehatan gigi dan mulut yang cukup tinggi di Indonesia dengan angka prevalensi pada semua kelompok umur adalah $96,58 \% .^{2}$ Penyakit periodontal ialah penyakit yang menyerang jaringan periodontal yang mengelilingi gigi dan berfungsi sebagai penyangga gigi. Jaringan periodontal terdiri dari gingiva, sementum, ligamen periodontal, dan tulang alveolar. Penyakit periodontal yang umum ditemukan yaitu gingivitis dan periodontitis.

Periodontitis merupakan inflamasi jaringan periodontal yang ditandai dengan migrasinya epitel jungsional ke arah apikal, kehilangan perlekatan dengan puncak tulang alveolar. Hasil pemeriksaan klinis menunjukkan adanya peningkatan kedalaman probing, pendarahan saat probing (di tempat aktifnya penyakit) yang dilakukan dengan perlahan dan terdapat perubahan kontur fisiologis. Hasil pemeriksaan klinis juga dapat menunjukkan kemungkinan ditemukannya kemerahan dan pembengkakan gingiva. Salah satu bakteri penyebab periodontitis yaitu bakteri Porphyromonas gingivalis. ${ }^{3}$ Penelitian yang dilakukan oleh Tomita et al. ${ }^{4}$ menunjukkan bahwa terdapat lebih banyak bakteri Porphyromonas gingivalis dan Tannerella forsythus pada penderita periodontitis serta jumlah kedua bakteri ini berbanding lurus dengan kedalaman poket gingiva saat probing pada penderita periodontitis yang diteliti. Bakteri ini dapat menyerang jaringan dan tulang alveolar pada hospes. Porphyromonas gingivalis merupakan bakteri anaerob Gram negatif yang dalam jumlah normal merupakan mikroflora normal yang bisa ditemukan dalam rongga mulut. ${ }^{5}$

Penanganan yang selama ini dilakukan dalam mengatasi penyakit periodontitis ini adalah menggunakan antibiotik tetapi sebagian besar masyarakat Indonesia terutama masyarakat di daerah pedesaan masih menggunakan obat-obatan herbal. Salah satu obat herbal yang cukup sering digunakan untuk mengatasi masalah gigi dan mulut yaitu cengkeh dengan penggunaan oleh mayoritas masyarakat yaitu dengan cara berkumur air cengkeh.

Cengkeh mengandung minyak atsiri yang memiliki senyawa eugenol. Senyawa eugenol berfungsi sebagai antibakteri terhadap beberapa bakteri patogen dalam rongga mulut. $^{6}$ Penelitian mengenai aktivitas antibakteri ekstrak bunga cengkeh telah dilakukan terhadap bakteri Streptococcus mutans namun terhadap bakteri Porphyromonas gingivalis belum pernah dilakukan. ${ }^{7}$

\section{BAHAN DAN METODE PENELITIAN}

Jenis penelitian ini ialah eksperimental laboratorium menggunakan rancangan eksperimental murni (true eksperimental design) dengan post test only control group design. Penelitian ini dilaksanakan di Laboratorium Farmasi Fakultas MIPA Universitas Sam Ratulangi Manado pada bulan Juni 2016.

Subjek penelitian ini ialah bakteri Porphyromonas gingivalis yang merupakan bakteri biakan murni diperoleh dari Laboratorium Mikrobiologi Fakultas Kedokteran Universitas Hasanuddin Makassar. Bunga cengkeh didapatkan dari Desa Senduk Tanawangko, Sulawesi Utara.

Ekstrak bunga cengkeh (Syzygium aromaticum) didapat melalui ekstraksi bunga cengkeh dengan metode maserasi menggunakan pelarut etanol $96 \%$. Pembuatan ekstrak bunga cengkeh dilakukan di Laboratorium Farmasi Fakultas MIPA Universitas Sam Ratulangi 
Manado.

Bakteri Porphyromonas gingivalis disimpan pada media Brain Heart Infusion Broth (BHI-B) kemudian dimasukkan ke dalam wadah steril yang berada dalam suasana tertutup, sehingga sterilisasi tetap terjaga. Jika sudah mendekati waktu untuk digunakan, bakteri diinkubasi pada suhu $37^{\circ} \mathrm{C}$ selama 24 jam. Pembuatan suspensi bakteri menggunakan media Brain Heart Infusion Broth (BHI-B). Pembuatan lapisan pembenihan dengan Muller-Hinton Agar (MHA).

Pembuatan larutan standar kekeruhan larutan McFarland yang terdiri atas dua komponen larutan yaitu larutan $\mathrm{BaCl}_{2} 1 \%$ dan $\mathrm{H}_{2} \mathrm{SO}_{4} 1 \%$. Larutan baku McFarland 0,5 ekuivalen dengan suspensi sel bakteri dengan konsentrasi $1,5 \times 10^{8} \quad \mathrm{CFU} / \mathrm{ml}$. Kekeruhan ini merupakan kekeruhan yang akan dipakai sebagai standar suspensi bakteri uji.

Peremajaan bakteri dan penanaman pada lapisan pembenihan bakteri Porphyromonas gingivalis yang disimpan di media agar yang diambil dengan menggunakan jarum ose steril, lalu ditanamkan pada media agar miring dengan cara menggores. Bakteri yang telah digores pada media agar diinkubasi dalam inkubator pada suhu $37^{\circ} \mathrm{C}$ selama $1 \times 24$ jam. Bakteri yang telah diinkubasi diambil koloninya dari media agar miring dengan menggunakan jarum ose steril. Koloni yang diambil dimasukkan ke dalam media BHIB sampai kekeruhannya sama dengan standar McFarland.

Pembuatan larutan kontrol positif dan kontrol negative, kontrol positif dibuat menggunakan sediaan tablet metronidazol 500 mg yang dihaluskan kemudian dicampur dengan pelarut aquades sebanyak $20 \mathrm{ml}$ hingga homogen. Etanol 96\% dipilih untuk digunakan sebagai kontrol negatif karena dalam pembuatan ekstrak bunga cengkeh menggunakan etanol $96 \%$ sebagai pelarut. Masing-masing larutan kontrol dimasukkan ke dalam sumur sebanyak 50 mikroliter dengan menggunakan mikropipet.

Metode pengujian yang digunakan dalam penelitian ini ialah metode modifikasi Kirby-Bauer dengan menggunakan sumuran. Media MHA yang digunakan sebanyak 5 cawan Petri dengan menggunakan 15 sumur. Lima sumur pertama yang sudah terbentuk pada media agar masingmasing media agar diisi dengan ekstrak bunga cengkeh yang sudah dilarutkan dengan etanol $96 \%$ sebagai kelompok intervensi. Lima sumur berikutnya pada masing-masing cawan Petri diisi dengan menggunakan metronidazol sebagai kelompok kontrol positif dan 5 sumur lainnya diisi menggunakan etanol 96\% sebagai kelompok kontrol negatif. Cawan Petri kemudian diinkubasi dalam inkubator pada suhu $37^{\circ} \mathrm{C}$ selama 24 jam. Setiap cawan petri berisi satu sumur kelompok intervensi, satu sumur kelompok kontrol positif dan satu sumur kelompok kontrol negatif.

Tabel 1. Perbandingan zona hambat terhadap Porphyromonas gingivalis

\begin{tabular}{cccc}
\hline \multirow{2}{*}{ Cawan Petri } & \multicolumn{3}{c}{ Diameter zona hambat yang terbentuk $(\mathrm{mm})$} \\
\cline { 2 - 4 } & $\begin{array}{c}\text { Ekstrak bunga } \\
\text { cengkeh }\end{array}$ & $\begin{array}{c}\mathrm{K}(+) \\
\text { Metronidazol }\end{array}$ & $\begin{array}{c}\mathrm{K}(-) \\
\text { Eugenol } 96 \%\end{array}$ \\
\hline I & 13,8 & 18,55 & 0 \\
II & 12,25 & 19,5 & 0 \\
III & 12,4 & 18,25 & 0 \\
IV & 14,05 & 18,75 & 0 \\
V & 12,55 & 18,85 & 0 \\
Total & 65,05 & 93,9 & 0 \\
Rerata & 13,01 & 18,78 & \\
\hline
\end{tabular}


Pengamatan dilakukan setelah 24 jam setelah masa inkubasi. Zona bening menunjukkan kepekaan bakteri terhadap bahan antibakteri yang digunakan sebagai bahan uji dan dinyatakan dengan diameter zona hambat.Zona hambat yang terbentuk di sekitar sumur diukur diameter vertikal dan diameter horizontal dengan menggunakan jangka sorong dan dinyatakan dalam satuan millimeter (mm). Pengukuran zona hambat (Gambar 1) dapat diukur menggunakan rumus:

$$
\frac{\left(D_{\mathrm{v}}-\mathrm{D}_{\mathrm{s}}\right)+\left(\mathrm{D}_{\mathrm{h}}-\mathrm{D}_{\mathrm{s}}\right)}{2}
$$

Keterangan :
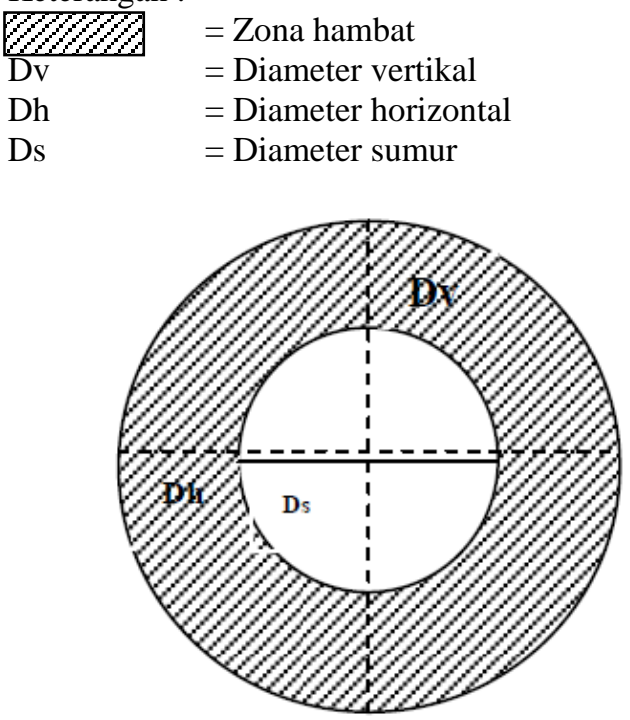

\section{HASIL PENELITIAN}

Hasil penelitian ini menunjukkan adanya daya hambat ekstrak bunga cengkeh (Syzygium aromaticum) terhadap bakteri Porphyromonas gingivalis. Daya hambat ditunjukkan dengan adanya zona bening yang terbentuk di sekitar sumur yang diisi dengan ekstrak bunga cengkeh. Hal yang sama juga dapat dilihat pada daerah sumur yang diisi metronidazol sedangkan pada daerah sumur yang diisi etanol $96 \%$ tidak terlihat adanya zona bening yang terbentuk.

Zona hambat yang terbentuk diukur diameter vertikal dan diameter horizontalnya menggunakan jangka sorong. Hasil pengukuran dinyatakan dalam satuan millimeter $(\mathrm{mm})$ kemudian dihitung menggunakan rumus pengukuran zona daya hambat (Tabel 1). Penelitian ini dilakukan sebanyak 5 kali pengulangan dengan hasil bervariasi.

Hasil pengukuran diameter zona hambat menunjukkan bahwa ekstrak bunga cengkeh memiliki nilai rerata $13,01 \mathrm{~mm}$, metronidazol memiliki nilai rerata 18,78 mm sedangkan eugenol tidak membentuk zona hambat.

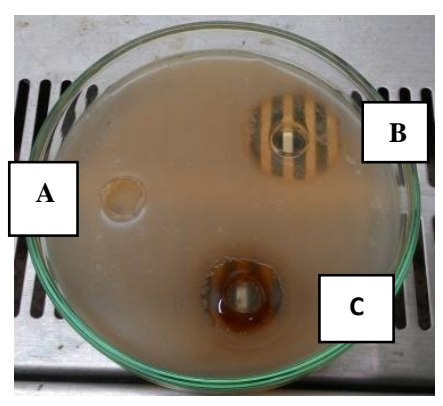

Gambar 2. Zona hambat yang terbentuk di media MHA. A, Etanol 90\%; B, zone hambat metronidazole; $\mathrm{C}$, zone hambat ekstrak bunga cengkeh.

\section{BAHASAN}

Hasil pengamatan pada kelima cawan petri menunjukkan bahwa ekstrak bunga cengkeh memiliki daya hambat terhadap bakteri Porphyromonas gingivalis yang ditunjukkan dengan adanya zona bening yang terbentuk di sekitar sumur yang diisi dengan ekstrak bunga cengkeh. Zona bening tersebut berwarna agak kehitaman yang dihasilkan oleh warna ekstrak bunga cengkeh.

Zona bening tersebut menunjukkan adanya aktivitas antibakteri dari minyak atsiri yang dihasilkan melalui proses ekstraksi bunga cengkeh. Aktivitas antibakteri minyak atsiri tergantung pada komponen serta persentase senyawa penyusunnya. ${ }^{8}$ Komponen utama minyak atsiri ekstrak bunga cengkeh yaitu eugenol dengan persentase 70-96\%. Eugenol merupakan salah satu senyawa golongan fenol yang bisa memiliki efek toksik terhadap bakteri. Bila senyawa golongan fenol menembus membran sel bakteri kemudian berinteraksi dengan enzim dan protein pada membran tersebut maka dapat menyebabkan aliran proton yang berlawanan sehingga bisa merusak aktivitas sel 
bakteri tersebut. ${ }^{9}$

Penelitian Gill dan Holly pada tahun 2006 menunjukkan mekanisme eugenol yaitu dengan cara menembus bagian membran sitoplasma dan mengganggu kemampuan permeabilitas dinding sel bakteri. Selain itu, sifat hydropobic (tidak larut dalam air) yang dimiliki eugenol lebih memudahkannya untuk masuk ke bagian lipopolisakarida dari membran sel bakteri khususnya bakteri Gram negatif dan mengubah struktur dinding sel. Struktur dinding sel yang berubah kemudian menyebabkan kebocoran pada bagian intrasel. ${ }^{10}$

Minyak atsiri bunga cengkeh juga dapat menghambat pertumbuhan bakteri Gram positif. Penelitian Andries tentang uji efek antibakteri ekstrak bunga cengkeh terhadap bakteri Streptococcus mutans secara in vitro menunjukkan adanya efek antibakteri berupa daya hambat terhadap bakteri golongan Gram positif tersebut. ${ }^{7}$ Selain terhadap beberapa bakteri, minyak atsiri cengkeh juga telah diujikan terhadap jamur Candida Albicans. Penelitian yang dilakukan oleh Pratiwi et al. ${ }^{11}$ pada tahun 2015 menunjukkan adanya daya hambat minyak atsiri cengkeh terhadap Candida albicans. Penelitian tersebut menggunakan minyak atsiri dari ekstrak daun cengkeh yang juga memiliki komponen utama eugenol.

Menurut penelitian Davis dan Stout $^{12}$ pada tahun 1971 mengenai kategori daya hambat maka ekstrak bunga cengkeh termasuk kategori kuat (11-20 mm) dalam menghambat bakteri Porphyromonas gingivalis karena memiliki rerata diameter zona hambat yaitu $13,01 \mathrm{~mm}^{12}$ Metronidazol yang digunakan sebagai kontrol positif juga termasuk memiliki daya hambat kategori kuat karena memiliki nilai rerata diameter $18,78 \mathrm{~mm}$. Metronidazol dipilih sebagai kontrol positif karena metronidazol merupakan salah satu antibiotik yang umum digunakan untuk perawatan penyakit periodontal. ${ }^{13,14}$ Mekanisme kerja metronidazol yaitu dengan cara menghambat sintesis asam nukleat. ${ }^{15}$ Walaupun keduanya termasuk kategori kuat, namun metronidazol memiliki diameter zona bening yang lebih besar dibandingkan ekstrak bunga cengkeh.

Di Finlandia Jarvinen et al. ${ }^{16}$ meneliti kepekaan Streptococcus mutans terhadap chlorhexidine dan 6 antimikroba in vitro. Salah satu faktor terbentuknya zona hambat yang optimal yaitu apakah minimum inhibitory concentration (MIC) telah diketahui agar mendapatkan konsentrasi yang paling tepat untu menghambat pertumbuhan bakteri, dalam hal ini Porphyromonas gingivalis. ${ }^{16}$ Metronidazol memiliki MIC terhadap bakteri Porphyromonas gingivalis sebesar $0,125 \mu \mathrm{g} / \mathrm{ml}$ sedangkan MIC senyawa aktif minyak atsiri ekstrak bunga cengkeh terhadap bakteri Porphyromonas gingivalis belum diketahui. ${ }^{17}$ Hal ini yang bisa menjadi salah satu penyebab rerata diameter zona hambat ekstrak bunga cengkeh lebih kecil dibanding rerata diameter zona hambat metronidazol.

\section{SIMPULAN}

Ekstrak bunga cengkeh (Syzygium aromaticum) memiliki daya hambat terhadap bakteri Porphyromonas gingivalis dengan rerata zona hambat $13,01 \mathrm{~mm}$ yang termasuk dalam kategori daya hambat kuat berdasarkan penggolongan Davis dan Stout.

\section{SARAN}

Diharapkan agar dilakukan penelitian lanjutan mengenai minimal inhibitor concentration (MIC) ekstrak bunga cengkeh (Syzygium aromaticum) terhadap bakteri Porphyromonas gingivalis.

\section{DAFTAR PUSTAKA}

1. Tampubolon NS. Dampak karies gigi dan penyakit periodontal terhadap kualitas hidup. [cited 19 Maret 2016]. Available from: http://library. usu.ac.id/download/e-book/Nurmala \%20Situmorang.pdf.

2. Nadya S, Erni M, Agustina, Eka F. Status kesehatan jaringan periodontal pada pasien diabetes mellitus tipe 2 dibandingkan dengan pasien nondiabetes mellitus berdasarkan GPI. 
[cited 19 Maret 2016]. Available from: http: //journal.unair.ac.id/ /eJournal\%20Status\%20kesehatan\%20j aringan\%20periodontal.pdf.

3. Fedi PF, Vernino AR, Gray JL. Silabus Periodonti (4th ed). Jakarta: EGC, 2012; p. 15, 21, 30-4.

4. Tomita S, Ito AK, Imamura K, Kita D, Ota K, Takayama S, et al. Prevalence of Aggregatibacter actinomycetem comitans, Porphyro-monas gingivalis, and Tannerella forsythus in Japanese patients with generalized chronic and aggressive periodontitis: Microbial pathogenesis. 2013; 61:11-5.

5. Rodriguez SB. Peptidiylarginine deiminase from Phorphyromonas gingivalis expressed in Escherichia coli: Enzyme characterization and catalytic mechanism. [cited 19 Maret 2016]. Available from: https://books.google. co.id/books?id=KOILos87JpsC\&prints $\mathrm{ec}=$ frontcover\&dq=porphyromonas $+\mathrm{gi}$ ngivalis\&hl $=\mathrm{id} \& \mathrm{sa}=\mathrm{X} \& \mathrm{ved}=0 \mathrm{CCcQ6}$ AEwAWoVChMIoozs0_awxwIVSpq $\mathrm{UCh} 2 \times 5 \mathrm{~g} 0 \mathrm{Q} \# \mathrm{v}=$ onepage $\& \mathrm{q}=$ porphyro monas\%20gingivalis\& $\mathrm{f}=$ false.

6. Kamatou GP, Vermaak I, Viljoen AM. Eugenol--from the remote Maluku Islands to the international market place: a review of a remarkable and versatilemolecule. Molecules. 2012;17( 6):6953-81.

7. Andries JR, Gunawan PN, Supit A. Uji efek antibakteri ekstrak bunga cengkeh terhadap bakteri Strepto-coccus mutans secara in vitro. e-G. 2014;2.

8. Nazzaro F, Fratianni F, Martino LD, Coppola R, Feo VD. Effect of essential oils on pathogenic bacteria.
Pharmacauticals. 2013; 6:1451-74.

9. Xing Y, Xu Q, Li X, Che Z, Yun J. Antifungal activities of clove oil against Rhizopus nigricans, Aspergillus flavus and Penicillium citrinum in vitro and in wounded fruit test. J Food Safety. 2012; 32:84-93.

10.Devi KP, Nisha SA, Sakthivel R, Pandian SK. Eugenol (an essential oil of clove) acts as an antibacterial agent against Salmonella typhi by disrupting the cellular membrane. J Ethnopharmacol. 2010;130:107-15.

11.Pratiwi DG, Suling PL, Leman MA. Uji daya hambat daun cengkeh (Syzygium aromaticum) dalam menghambat pertumbuhan Candida albicans. Dentire. 2015; 4:27-31.

12.Davis WW, Stout TR. Disc plate method of microbiological antibiotic assay. J Appl Microbiol. 1971;22(4): 659-65.

13. Balaji SM. Textbook of Oral \& Maxillofacial Surgery. New Delhi: Elsevier, 2009; p. 153.

14. Krismariono A. Antibiotika sistemik dalam perawatan penyakit periodontal. Periodontic Journal. 2009; 1:15-9.

15. Haveles EB. Applied Pharmacology for the Dental Hygienist (6th ed). Missouri: Mosby Elsevier, 2011; p. 90.

16. Jarvinen H, Tenovuo J, Huovinen P. In vitro susceptibility of Streptococcus mutans to clorhexidine and six other antimicrobial agents. Journal ASM. 1993; 37: 1158-9.

17. Wright TL, Ellen RP, Lacroix JM, Sinnadurai S, Mittelman MW. Effect of metronidazole on Porphyro-monas gingivalis biofilms. J Periodontal Res. 1997; 32: 473-7 